\title{
Silvina Chemen and Franciso Canzani A Dialogue of Life: Towards the Encounter of Jews and Christians
}

(New York: New City Press of the Focolare and the Jewish Theological Seminary, 2015), paperback, xii + 189 pp.

\author{
MARCUS BRAYBROOKE \\ marcusbraybrooke4@gmail.com \\ World Congress of Faiths, London, W1T 4PW, UK
}

This book was a welcome surprise. I expected another summary of the key developments in Christian-Jewish dialogue, such as are found in statements by various churches. Instead, the book focuses on the dynamics of interreligious dialogue itself, which Silvina Chemen and Francisco Canzani have discovered in their long partnership. Another welcome surprise is that in the book we hear voices from Latin America.

Rabbi Silvina Chemen studied education at the University of Buenos Aires and then attended rabbinical school. She now serves a congregation in Buenos Aires. Francisco Canzani grew up in Uruguay and now teaches Ecumenical Theology at the University of Montevideo. A consecrated lay person, he has been much influenced by the Catholic Focolare Movement, which was founded by Chiara Lubich and which emphasizes dialogue as an important contribution to building a better world. In some sections, the authors express their own views; other sections are jointly authored.

Francisco begins by emphasizing the importance of interreligious dialogue, which involves a "dual allegiance" (p. 28) of loyalty to the gifts that God has given us in our respective traditions and "faithfulness to the project of universal brotherhood that God harbors for humanity" (p. 30). Silvina speaks of dialogue as "our hope for healing." The authors largely focus on methodologies of JewishChristian dialogue (such as overcoming stereotypes and the relationship between intrareligious and interreligious dialogue) and discuss some of the stumbling blocks (such as concerns about missionizing). The starting point is to build trust. Silvina makes clear that this takes time and "requires perseverance, commitment and some risk" (p. 47). (I learned this myself as a member of the Manor House Group in Britain, which hosted a regular dialogue of Jewish and Christian clergy for nearly ten years, though larger, less frequent dialogues have both a symbolic importance and promote practical co-operation in the search for peace and the protection of human rights.) 
Silvina and Francisco insist that real listening is essential: "Without listening, we don't understand and will never get close to the other" (p. 69). This message is reinforced in the Afterword. They quote the Argentinian Archbishop of Resistencia, the Most Reverend Ramon Alfredo Dus, who says "Without silence, words lose density and content... We allow the one before us to speak and express himself by being silent instead of clinging to our words and ideas" (p. 177). Rabbi Daniel Goldman of the Community of Beth El in Buenos Aires, in his "Ten Principles for Dialogue," emphasizes the personal nature of the "I-Thou" relationship. He quotes the story Martin Buber told of a time when he was a university counselor and a young student shared with him his feelings of despair: "Busy with other matters, Buber did not give much importance to the conversation. The next day he read in the university newspaper that his student had committed suicide" (p. 171).

They give considerable attention to the art of asking questions of others with sensitivity. It is particularly important not to make the other feel defensive. Silvina recounts her experience being asked, following a talk she had given in a Catechetical Seminary, "Why don't you believe in Jesus Christ?" She replied, "This question does not do any good to anyone. Do you intend... to draw us apart again?...We have learned not to slap with a question" (p. 85). Dialogue, they insist, does not involve any dilution of a person's beliefs. Still, many people find their perspectives and self-understanding change as they participate in dialogue. For example, as Christians have learned more about Jews and Judaism, the views of individual Christians and the teachings of the churches have changed, as Rabbi Jack Bemporand, the Director of the Centre for Interreligious Understanding in New Jersey, makes clear in his Prologue.

In light of this focus, they are less interested in historical or theological issues. Different ways of thinking theologically in the rabbinic and the Christian traditions (the latter much influenced by Greek philosophical ideas) are largely ignored, though this may explain some continuing tensions in Jewish-Christian relations. (For works that grapple with this divide, evident for example in Christian creeds, see Mary Boys' Has God Only One Blessing? [2000] or Hans Küng's Judaism [1992].) It is not, however, the purpose of this book to discuss such questions. Its approach is more practical, and it will be very helpful for those starting a dialogue group. Even for those with long experience of dialogue, the book will encourage them to look self-critically at their own approach. Indeed, as one woman said after she had heard talks by Silvina and Francisco, their insights are "useful not only for interreligious dialogue, but also for all other dialogues, in our homes, in our jobs. How many times we pretend we are listening while all we are doing is preparing our response" (pp. 168-69).

(The book was first published in Spanish as Un Diálogo Para la Vida: Haciael Encuentro Emtre Judios y Cristianos: A dos Voces y al Unison, Buenos Aires: Ciudad Nueva, 2013.) 